Journal of Animal and Veterinary Advances 11 (5): 665-675, 2012

ISSN: $1680-5593$

(C) Medwell Journals, 2012

\title{
Effect of Dietary Energy Density on Performance and Lean Deposition of Growing-Finishing Pigs
}

\author{
L.C. Chu, G.J. Zhang, C.J. Cai, X.B. Mao and S.Y. Qiao \\ State Key Laboratory of Animal Nutrition, China Agricultural University, \\ No. 2 Yuanmingyuan, West Road, 100193 Beijing, P.R. China
}

\begin{abstract}
Three experiments using a total of 1140 crossbred barrows and gilts (Yorkshire $\mathrm{x}$ Landrace $\mathrm{x}$ Duroc) were conducted to determine the effects of dietary Digestible Energy (DE) density on performance and lean deposition in growing-finishing pigs during three separate phases. A completely randomized block design within sex was used involving 480 pigs in Exp. $1(20.8-55.9 \mathrm{~kg}), 420$ pigs in Exp. $2(57.0-76.6 \mathrm{~kg})$ and 240 pigs in Exp. 3 (78.6-105.8 kg) (pigs were from three different groups). Pigs were allotted to one of five treatments containing $13.62,13.87,14.12,14.37$ and $14.62 \mathrm{MJ} \mathrm{DE} \mathrm{kg}{ }^{-1}$. Pig body weight and feed consumption were determined every 2 weeks and carcass composition was evaluated at the start and end of the experiments. The quadratic or broken-line model was used to estimate the requirement of dietary DE concentration. In Exp. 1, there were no differences ( $p>0.05$ ) in weight gain or feed efficiency. Meanwhile, carcass fat-free lean gain decreased (linear, $\mathrm{p}=0.02$; quadratic, $\mathrm{p}=0.02$ ) and fat-free lean index decreased quadratically (quadratic, $\mathrm{p}=0.05$ ) with increasing dietary energy density. The optimum dietary DE to maximize lean deposition was calculated to be $13.81 \mathrm{MJ} \mathrm{DE} \mathrm{kg}^{-1}$. In Exp. 2, for pigs weighing $57.0-76.6 \mathrm{~kg}$ both weight gain (linear, $p=0.02$ ) and feed efficiency (linear, $p=0.02$ ) increased linearly with increasing DE density while carcass fat-free lean gain $(p=0.05)$ and fat-free lean index decreased $(p<0.01)$. The optimum dietary $\mathrm{DE}$ for lean deposition was 13.76 MJ DE kg ${ }^{-1}$. In Exp. 3, the linearly decreased feed intake (linear $\mathrm{p}=0.04$ ) and increased weight gain (linear, $\mathrm{p}<0.01$; quadratic, $\mathrm{p}=0.01$ ) resulted in an improvement in feed efficiency (linear, $\mathrm{p}<0.01$; quadratic, $\mathrm{p}=0.01$ ). The quadratically decreased carcass fat-free lean gain (quadratic, $\mathrm{p}=0.02$ ) and decreased fat-free lean index $(\mathrm{p}<0.01)$ suggested that the optimum dietary $\mathrm{DE}$ for lean deposition was calculated to be $13.82 \mathrm{MJ} \mathrm{DE} \mathrm{kg}{ }^{-1}$.
\end{abstract}

$\underline{\text { Key words: Digestible energy, growing-finishing pigs, growth performance, lean deposition, producer, China }}$

\section{INTRODUCTION}

An evaluation of the relationship between dietary energy and performance or tissue deposition is usually based on energy intake (Campbell and Dunkin, 1983; Kyriazakis and Emmans, 1992a, b; Weis et al., 2004). In commercial environments, free access to feed is commonly used which dictates that researcher can modulate the energy intake of pigs only by compounding diets with different energy levels and not by altering feeding levels.

Many studies have been conducted to investigate the energy range which maximizes pig performance. Black (1995) suggested that the critical lower limit would be 13.77 MJ D E kg-1 for pigs weighing 20-50 kg and $9.83 \mathrm{MJ} \mathrm{DE} \mathrm{kg}^{-1}$ for pigs $>50 \mathrm{~kg}$. King (1999) found that the performance of growing pigs would not be impaired at dietary DE concentrations above $14.5 \mathrm{MJ} \mathrm{kg}^{-1}$. However, in the NRC (1998) recommendations, dietary DE requirement for all growing-finishing pigs was all $3400 \mathrm{kcal} \mathrm{kg}^{-1}\left(14.2 \mathrm{MJ} \mathrm{kg}^{-1}\right)$.

In economic terms, the amount of lean tissue and its distribution are of prime concern for pig producers and these are the main determinants of the amount and quality of pork that can be derived from the pig's carcass. To satisfy consumer demands for leaner pork, recent emphasis in the pork industry has been to maximize lean growth in pigs through genetic selection and nutrition (Lawrence et al., 1994).

Noblet et al. (1989) showed that the energy requirements for protein and lipid deposition were 9.7 and $15.9 \mathrm{~kJ} \mathrm{~g}^{-1}$, respectively. Thus, it is possible that the energy requirement for lean deposition is different from that for the growth of the whole body. The objective of this study was to determine the effect of dietary energy

Corresponding Author: S.Y. Qiao, State Key Laboratory of Animal Nutrition, China Agricultural University, No. 2 Yuanmingyuan West Road, 100193 Beijing, P.R. China 
density (ranging from 13.62-14.62 $\mathrm{MJ} \mathrm{DE} \mathrm{kg}{ }^{-1}$ ) on performance and lean deposition of growing-finishing pigs $(20.8-55.9,57.0-76.6$ and $78.6-105.8 \mathrm{~kg})$.

\section{MATERIALS AND METHODS}

The procedures used in these experiments followed those proposed by the China Agriculture University Animal Care and Use Committee (Beijing, China). The experiments were conducted at a commercial swine farm located in Hunan province (Yiyang city, China).

Animals and feeding: Three experiments were conducted to evaluate the effects of increasing dietary energy density on performance and lean deposition of growing-finishing pigs over three phases (20.8-55.9, $57.0-76.6$ and $78.6-105.8 \mathrm{~kg}$ ). A completely randomized block design within sex was used. Pigs (Yorkshire $\mathrm{x}$ Landrace $\mathrm{x}$ Duroc) were allotted to one of five treatments $\left(13.62,13.87,14.12,14.37\right.$ and 14.62 MJ DE kg $\left.{ }^{-1}\right)$ with the treatments applied to six pens containing an equal number of barrows and gilts. The pigs were raised in pens with concrete floors that were half solid and half slatted. Different pigs were used for the three experiments to avoid any potential for a residual effect of treatment in one phase affecting the performance in the other phase.

The DE concentration of the treatment diets was increased by changing the ratio of low to high energy ingredients. Wheat bran was chosen as the low energy ingredient and corn and soybean oil as high energy ingredients. The range of energy between $\mathrm{DE}$ treatment concentrations was $0.25 \mathrm{MJ} \mathrm{kg}^{-1}\left(60 \mathrm{kcal} \mathrm{kg}^{-1}\right)$ this range exceeds the variability within cereal grains of $53 \mathrm{kcal}$ (Fairbairn et al., 1999) allowing differences to be more readily attributed to treatment and not to ingredient variability. Digestible energy values for individual feed ingredients were previously determined in the laboratory and were used to calculate the DE content of the diets. The DE values were $14.06 \mathrm{MJ} \mathrm{DE} \mathrm{kg} \mathrm{kg}^{-1}$ for corn,

Table 1: Nutrient values of ingredients used in Experiments 1-3

\begin{tabular}{lccc}
\hline Nutrient values & Corn & Soybean meal & Wheat bran \\
\hline Dry matter (\%) & 88.41 & 89.23 & 89.48 \\
Ash (\%) & 1.98 & 5.54 & 5.05 \\
Crude protein (\%) & 8.31 & 45.08 & 17.47 \\
Ether extract (\%) & 4.07 & 1.96 & 2.95 \\
Starch (\%) & 70.56 & 11.70 & 28.37 \\
Crude fiber (\%) & 2.22 & 6.10 & 9.98 \\
NDF (\%) & 12.58 & 25.62 & 35.85 \\
ADF (\%) & 1.97 & 7.83 & 9.69 \\
Gross energy (\%) & 16.25 & 17.71 & 16.34 \\
Digestible energy ${ }^{x}\left(\mathrm{MJ} \mathrm{kg}^{-1}\right)$ & 14.06 & 15.88 & 10.41 \\
\hline xigestible energy of ingredients was determined previously by total \\
collection method in growing pigs in the lab
\end{tabular}

15.88 $\mathrm{MJ} \mathrm{DE} \mathrm{kg}^{-1}$ for soybean meal and 10.41 MJ DE kg ${ }^{-1}$ for wheat bran (Table 1). The DE value for soybean oil of $36.61 \mathrm{MJ} \mathrm{kg}^{-1}$ was obtained from the China Feed Bank (2006). All diets were formulated to meet or exceed the NRC (1998) recommended levels for other nutrients. Feed samples were collected in each trial and analyzed for their chemical composition (Table 2-4).

Table 2: Ingredient and nutrient composition of experimental diets for 20.8-55.9 kg phase pigs containing five energy levels (Exp. 1 as fed basis)

\begin{tabular}{|c|c|c|c|c|c|}
\hline \multirow[b]{2}{*}{ Experimental diets } & \multicolumn{5}{|c|}{$\mathrm{DE}^{\mathrm{x}}\left(\mathrm{MJ} \mathrm{kg}^{-1}\right)$} \\
\hline & 13.62 & 13.87 & 14.12 & 14.37 & 14.62 \\
\hline \multicolumn{6}{|l|}{ Ingredients (\%) } \\
\hline Corn & 50.40 & 56.45 & 59.65 & 60.10 & 60.85 \\
\hline Soybean meal & 30.80 & 31.10 & 31.00 & 31.70 & 31.80 \\
\hline Wheat bran & 15.80 & 9.50 & 6.00 & 4.15 & 2.50 \\
\hline Soybean oil & 0.00 & 0.00 & 0.50 & 1.25 & 2.05 \\
\hline Salt & 0.40 & 0.40 & 0.40 & 0.40 & 0.40 \\
\hline Medical stone & 0.20 & 0.15 & 0.05 & 0.00 & 0.00 \\
\hline Dicalcium phosphate & 0.40 & 0.40 & 0.40 & 0.40 & 0.40 \\
\hline Limestone, ground & 1.00 & 1.00 & 1.00 & 1.00 & 1.00 \\
\hline Vitamin/Mineral premix ${ }^{\mathrm{y}}$ & 1.00 & 1.00 & 1.00 & 1.00 & 1.00 \\
\hline \multicolumn{6}{|l|}{ Analyzed nutrients (\%) } \\
\hline Crude protein & 17.94 & 18.01 & 18.06 & 18.11 & 18.09 \\
\hline Calcium & 0.71 & 0.70 & 0.66 & 0.69 & 0.66 \\
\hline Phosphorus & 0.54 & 0.54 & 0.57 & 0.55 & 0.53 \\
\hline Lysine & 0.98 & 0.97 & 0.95 & 0.94 & 0.95 \\
\hline Methionine & 0.28 & 0.25 & 0.25 & 0.27 & 0.25 \\
\hline Tryptophan & 0.19 & 0.17 & 0.17 & 0.17 & 0.18 \\
\hline Threonine & 0.70 & 0.69 & 0.66 & 0.66 & 0.65 \\
\hline
\end{tabular}

Table 3: Ingredient and nutrient composition of experimental diets for $57.0-76.6 \mathrm{~kg}$ phase pigs containing five energy levels (Exp. 2 as fed basis)

\begin{tabular}{|c|c|c|c|c|c|}
\hline \multirow[b]{2}{*}{ Experimental diets } & \multicolumn{5}{|c|}{$\mathrm{DE}^{\mathrm{x}}\left(\mathrm{MJ} \mathrm{kg}^{-1}\right)$} \\
\hline & 13.62 & 13.87 & 14.12 & 14.37 & 14.62 \\
\hline \multicolumn{6}{|l|}{ Ingredients (\%) } \\
\hline Corn & 66.40 & 72.30 & 71.70 & 72.40 & 72.55 \\
\hline Soybean meal & 20.40 & 21.00 & 21.30 & 21.50 & 21.50 \\
\hline Wheat bran & 10.00 & 3.50 & 2.80 & 1.10 & 0.00 \\
\hline Soybean oil & 0.00 & 0.00 & 1.00 & 1.80 & 2.75 \\
\hline Salt & 0.40 & 0.40 & 0.40 & 0.40 & 0.40 \\
\hline Dicalcium phosphate & 1.00 & 1.00 & 1.00 & 1.00 & 1.00 \\
\hline Limestone, ground & 0.80 & 0.80 & 0.80 & 0.80 & 0.80 \\
\hline Vitamin/Mineral mix & 1.00 & 1.00 & 1.00 & 1.00 & 1.00 \\
\hline \multicolumn{6}{|c|}{ Analyzed nutrients (\%) } \\
\hline Crude protein & 14.83 & 14.83 & 14.81 & 14.81 & 14.79 \\
\hline Calcium & 0.59 & 0.58 & 0.59 & 0.57 & 0.58 \\
\hline Phosphorus & 0.47 & 0.47 & 0.43 & 0.45 & 0.43 \\
\hline Lysine & 0.78 & 0.78 & 0.76 & 0.77 & 0.75 \\
\hline Methionine & 0.23 & 0.24 & 0.22 & 0.25 & 0.26 \\
\hline Tryptophan & 0.17 & 0.15 & 0.18 & 0.17 & 0.16 \\
\hline Threonine & 0.59 & 0.59 & 0.57 & 0.63 & 0.61 \\
\hline
\end{tabular}

${ }^{x}$ Calculated according to digestible energy values of corn, soybean meal and wheat determined in the lab; digestible energy value of soybean oil was obtained from the China Feed Bank (2006); 'Premix provided the following per $\mathrm{kg}$ of complete diet for Exp. 1 and 2: vitamin A, 5,512 IU; vitamin D3, 2,200 IU; vitamin E, $64 \mathrm{IU}$; vitamin $\mathrm{K} 3,2.2 \mathrm{mg}$; vitamin $\mathrm{B} 12,27.6 \mu \mathrm{g}$; riboflavin, $5.5 \mathrm{mg}$; pantothenic acid, $13.8 \mathrm{mg}$; niacin, $30.3 \mathrm{mg}$; choline chloride, $551 \mathrm{mg}$; Mn, $10 \mathrm{mg}$; Fe, $100 \mathrm{mg}$; Zn, $100 \mathrm{mg}$; $\mathrm{Cu}, 20 \mathrm{mg} ; \mathrm{I}, 0.3 \mathrm{mg} ; \mathrm{Se}, 0.3 \mathrm{mg}$ 
Table 4: Ingredient and nutrient composition of experimental diets for 78.6-105.8 kg phase pigs containing five energy levels (Exp. 3 as fed basis)

\begin{tabular}{|c|c|c|c|c|c|}
\hline \multirow[b]{2}{*}{ Experimental diets } & \multicolumn{5}{|c|}{$\mathrm{DE}^{\mathrm{x}}\left(\mathrm{MJ} \mathrm{kg}^{-1}\right)$} \\
\hline & 13.62 & 13.87 & 14.12 & 14.37 & 14.62 \\
\hline \multicolumn{6}{|l|}{ Ingredient (\%) } \\
\hline Corn & 76.00 & 77.90 & 79.90 & 79.00 & 76.00 \\
\hline Soybean meal & 13.20 & 14.10 & 15.10 & 15.40 & 15.30 \\
\hline Wheat bran & 8.00 & 4.70 & 1.20 & 0.80 & 2.50 \\
\hline Soy oil & 0.00 & 0.50 & 1.00 & 2.00 & 3.40 \\
\hline Salt & 0.30 & 0.30 & 0.30 & 0.30 & 0.30 \\
\hline Dicalcium phosphate & 0.70 & 0.70 & 0.70 & 0.70 & 0.70 \\
\hline Limestone, ground & 0.80 & 0.80 & 0.80 & 0.80 & 0.80 \\
\hline Vitamin/Mineral mix & 1.00 & 1.00 & 1.00 & 1.00 & 1.00 \\
\hline \multicolumn{6}{|l|}{ Analyzed nutrients (\%) } \\
\hline Crude protein & 13.79 & 13.84 & 13.87 & 13.77 & 13.77 \\
\hline Calcium & 0.53 & 0.51 & 0.52 & 0.50 & 0.51 \\
\hline Phosphorus & 0.41 & 0.43 & 0.43 & 0.40 & 0.42 \\
\hline Lysine & 0.61 & 0.60 & 0.59 & 0.58 & 0.58 \\
\hline Methionine & 0.21 & 0.23 & 0.22 & 0.20 & 0.21 \\
\hline Tryptophan & 0.14 & 0.13 & 0.13 & 0.12 & 0.11 \\
\hline Threonine & 0.47 & 0.47 & 0.46 & 0.47 & 0.45 \\
\hline
\end{tabular}

${ }^{x}$ Calculated according to digestible energy values of corn, soybean meal and wheat determined in the lab; digestible energy value of soybean oil was obtained from the China Feed Bank (2006); 'Premix provided the following per kg of complete diet for Exp. 3: vitamin A, 2,512 IU; vitamin D3, 1,200 $\mathrm{IU}$; vitamin $\mathrm{E}, 34 \mathrm{IU}$; vitamin $\mathrm{K} 3,1.5 \mathrm{mg}$; vitamin $\mathrm{B} 12,17.6 \mu \mathrm{g}$; riboflavin, $2.5 \mathrm{mg}$; pantothenic acid, $6.8 \mathrm{mg}$; niacin, $20.3 \mathrm{mg}$; choline chloride, $351 \mathrm{mg}$; $\mathrm{Mn}, 10 \mathrm{mg}$; $\mathrm{Fe}, 50 \mathrm{mg} ; \mathrm{Zn}, 50 \mathrm{mg}$; Cu, $10 \mathrm{mg}$; , $0.3 \mathrm{mg}$; Se, $0.3 \mathrm{mg}$

In Exp. 1, a total of 480 pigs with an initial body weight of $20.8 \pm 2.1 \mathrm{~kg}$ were used during the $20.8-55.9 \mathrm{~kg}$ phase. Sixteen pigs were reared in pens measuring $5.21 \times 2.85 \mathrm{~m}$. In Exp. 2 , a total of 420 pigs $(57.0 \pm 2.7 \mathrm{~kg})$ were used during the $57.0-76.6 \mathrm{~kg}$ phase with 14 pigs per pen $(5.62 \times 2.53 \mathrm{~m})$. In Exp. 3, a total of 240 pigs $(78.6 \pm 3.2 \mathrm{~kg})$ were used for the 78.6-105.8 kg phase with eight pigs per pen $(4.65 \times 2.40 \mathrm{~m})$. Prior to starting the experiment, the pigs were all fed a commercially prepared grower diet and housed in a different barn to that used for the present experiment. Diets and water were provided ad libitum throughout these three experiments. Pigs were weighed and feed disappearance was measured every 14 days to determine weight gain, feed intake and feed efficiency.

Carcass evaluation: At the beginning of each experiment, six additional pigs obtained from the same source as those used in the experiment with an initial body weight of 20.8 (Exp. 1), 57.0 (Exp. 2) and $78.6 \mathrm{~kg}$ (Exp. 3) were weighed and then transported to a processing plant where carcass data were collected to obtain initial carcass composition. Pigs were killed by exsanguination immediately following electrical stunning. Hot carcass weight was measured to determine dressing percentage. Carcass measurements including longissimus muscle area, the 10th rib back fat depth and last-rib back fat depth were obtained from the left side of the hot carcass according to the method decribed by Johnson et al. (2004). In addition, carcass fat-free lean weight was calculated using the equations in NRC (1998). When pigs reached the target slaughter body weight, they were fasted on the morning of the day of slaughter. One randomly selected pig from each pen was slaughtered by the previously described method and the final carcass data were collected.

NRC (1998) equations were used to evaluate fat-free lean content ( $1 \mathrm{~b}$ and in. was converted to $\mathrm{g}$ and $\mathrm{cm}$, respectively in the study):

$$
\begin{aligned}
& \text { Carcass fat }- \text { free lean }(1 \mathrm{~b})=0.95 \times[7.231+(0.437 \times \\
& \text { Hot carcass weight, } 1 \mathrm{~b})-(18.746 \times 10 \text { th back fat } \\
& \text { depth, in } \left.)+\left(3.877 \times 10 \text { th rib loin eye area, } \text { in }^{2}\right)\right] \\
& \text { Carcass fat }- \text { free lean gain }\left(1 \mathrm{~b} \text { day }{ }^{-1}\right)= \\
& {[(\text { Final carcass fat }- \text { free lean, } 1 \mathrm{~b})} \\
& \frac{(\text { Initial carcass fat }- \text { free lean, } 1 \mathrm{~b})]}{\text { Days from initial to final }}
\end{aligned}
$$

Fat-free lean index $=[50.767+(0.035 \times$

Hot carcass weight, 1b)-( $8.979 \times$ last-

rib midline backfat on hot carcass, in)]

Chemical analysis: All analyses were performed in duplicate. The analysis of the proximate principles was conducted according to standard procedures (AOAC, 1990). Gross energy was determined by an automatic adiabatic oxygen bomb calorimeter (Parr 1281 Automatic Energy Analyzer, Moline, IL). Phosphorus content was analyzed using a UV-visible spectrophotometer (Hitachi, U-1000, Tokyo, Japan).

The amino acid content of the diets was determined by High Performance Liquid Chromatography (Hitachi L8800 Amino Acid Analyzer, Tokyo, Japan) after $24 \mathrm{~h}$ hydrolysis with $6 \mathrm{NHCl}$ in closed glass vessels according to AOAC (1990). Methionine and cysteine were determined after oxidation with performic acid (Llames and Fontaine, 1994). The tryptophan concentration of the diets was determined by reversed-phase HPLC following alkaline hydrolysis according to AOAC (1990).

Statistical analysis: Data for each response criterion were analyzed by ANOVA using the GLM procedure (SAS Inst. Inc., Cary, NC) with energy density and replicate included in the model. The pen was considered to be the experimental unit. Energy density effects on performance and lean deposition were evaluated by linear and quadratic contrasts and the qudratic or broken-line 
regression model was used for response variables to obtain an estimate of the dietary $\mathrm{DE}$ requirement (Robbins et al., 2006). The two models could not be used to estimate requirements for growth variables either due to a lack of response to energy concentration or because there was no breakpoint in the data. Carcass fat-free lean gain and fat-free lean index were the dependent variables to determine the dietary $\mathrm{DE}$ requirements for lean deposition. The least square means procedure of SAS was used to calculate mean values and the pair-wise t-tests was used to determine differences between treatment means. Differences were considered significant at $\mathrm{p}<0.05$ and highly significant at $\mathrm{p}<0.01$.

\section{RESULTS AND DISCUSSION}

Growth performance: Weight gain $(p=0.21)$ and feed efficiency ( $p=0.47$ ) was not different during the 20.8-55.9 kg period (Table 5). Feed intake was affected significantly $(\mathrm{p}=0.02)$. Dietary DE intake (DEi) increased (linear, $\mathrm{p}<0.01$; quadratic, $\mathrm{p}<0.01$ ) with increasing $\mathrm{DE}$ during this time period.

In Exp. 2, during the $57.0-76.6 \mathrm{~kg}$ period, increasing the dietary DE concentration from $13.62-14.62 \mathrm{MJ} \mathrm{DE} \mathrm{kg}^{-1}$ resulted in an increase of $>0.09 \mathrm{~kg} \mathrm{day}^{-1}$ of weight gain $(\mathrm{p}=0.01)$ and a linear decrease of $0.10 \mathrm{~kg}$ day $^{-1}$ of feed intake (linear, $\mathrm{p}=0.02$ ).

There was no difference in DE intake during this period $(p=0.72)$. Feed efficiency improved (linear, $p<0.01$; quadratic, $\mathrm{p}=0.07$ ) with increasing energy levels (Table 5). Pigs in Exp. $3(78.6-105.8 \mathrm{~kg})$ fed diets containing lower energy contents grew at a lower rate than pigs fed higher energy diets (linear, $\mathrm{p}<0.01$; quadratic, $\mathrm{p}=0.01$, Table 5).
The linearly decreased feed intake (linear $p=0.04$ ) and increased weight gain (linear, $\mathrm{p}<0.01$; quadratic, $\mathrm{p}=0.01$ ) resulted in an improvement in feed efficiency (linear, $\mathrm{p}<0.01$; quadratic, $\mathrm{p}=0.01$ )

Lean deposition: During the $20.8-55.9 \mathrm{~kg}$ period, there was a quadratic response in longissimus muscle area (quadratic, $\mathrm{p}<0.01$ ) and a decrease in carcass fat-free lean gain (linear, $\mathrm{p}=0.02$; quadratic, $\mathrm{p}=0.02$ ) as $\mathrm{DE}$ concentration increased. For fat-free lean index, a negative trend (quadratic, $\mathrm{p}=0.05$ ) was present (Table 6).

Increasing the dietary $\mathrm{DE}$ concentration from 13.62-14.62 $\mathrm{MJ} \mathrm{DE} \mathrm{kg}^{-1}$ resulted in an increase of $>8.8 \mathrm{~mm}$ of back fat depth (linear, $\mathrm{p}<0.01$; quadratic, $\mathrm{p}<0.01$ ) in the $57.0-76.6 \mathrm{~kg}$ period. However, longissimus muscle area was decreased (linear, $p=0.03$ ). Furthermore, for carcass fat-free lean gain and fat-free lean index, decreased values (linear, $\mathrm{p}<0.01$; quadratic, $\mathrm{p}<0.01$ ) were observed although, carcass fat-free lean gain at the level of $13.87 \mathrm{MJ} \mathrm{kg}^{-1}$ was numerically higher than those of the other treatments (Table 6).

Increased 10 th rib back fat depth was present in the 78.6-105.8kg period(linear, $\mathrm{p}<0.01$; quadratic, $\mathrm{p}<0.01$ ) with the highest value of $2.32 \mathrm{~cm}$ at the level of $14.62 \mathrm{MJ} \mathrm{kg}^{-1}$. Longissimus muscle area was linearly decreased (linear, $\mathrm{p}<0.01)$. There was a quadratic response in fat-free lean gain (quadratic, $\mathrm{p}=0.02$ ) and a decrease (linear, $\mathrm{p}<0.01$; quadratic, $p<0.01$ ) in fat-free lean index with increasing the dietary DE concentration.

The optimum energy density to maximize lean deposition is defined as the DE level which supports maximum fat-free lean gain and fat-free lean index,

Table 5: Effects of dietary energy density on growth performance of growing-finishing pigs reared in a commercial environment ${ }^{\mathrm{x}}$

\begin{tabular}{|c|c|c|c|c|c|c|c|c|c|}
\hline \multirow[b]{2}{*}{ Effects } & \multicolumn{5}{|c|}{$\mathrm{DE}\left(\mathrm{MJ} \mathrm{kg}^{-1}\right)$} & \multirow[b]{2}{*}{ SEM } & \multicolumn{3}{|l|}{$\mathrm{p}^{\mathrm{y}}$} \\
\hline & 13.62 & 13.87 & 14.12 & 14.37 & 14.62 & & ANOVA & Linear & Quadratic \\
\hline \multicolumn{10}{|l|}{$20.8-55.9 \mathrm{~kg}$} \\
\hline Initial BW (kg) & 20.82 & 20.74 & 20.81 & 20.72 & 20.84 & 0.05 & 1.00 & 0.99 & 1.00 \\
\hline Final BW (kg) & 56.67 & 55.28 & 55.00 & 56.26 & 56.41 & 0.74 & 0.93 & 0.92 & 0.73 \\
\hline Weight gain $\left(\mathrm{kg} \mathrm{day}^{-1}\right)$ & 0.80 & 0.77 & 0.76 & 0.79 & 0.79 & 0.01 & 0.21 & 0.82 & 0.15 \\
\hline Feed intake $\left(\mathrm{kg} \mathrm{day}^{-1}\right)$ & $1.55^{\mathrm{ab}}$ & $1.47^{\mathrm{bc}}$ & $1.45^{\mathrm{c}}$ & $1.57^{\mathrm{a}}$ & $1.56^{\mathrm{ab}}$ & 0.03 & 0.02 & 0.35 & 0.05 \\
\hline Feed efficiency & 0.52 & 0.53 & 0.53 & 0.50 & 0.51 & 0.00 & 0.47 & 0.35 & 0.38 \\
\hline Digestible energy intake (MJ day ${ }^{-1}$ ) & $21.15^{b}$ & $20.33^{b}$ & $20.43^{b}$ & $22.51^{\mathrm{a}}$ & $22.76^{\mathrm{a}}$ & 1.14 & 0.02 & $<0.01$ & $<0.01$ \\
\hline \multicolumn{10}{|l|}{$57.0-76.6 \mathrm{~kg}$} \\
\hline Initial BW (kg) & 56.11 & 57.58 & 56.43 & 58.25 & 56.42 & 0.92 & 0.99 & 0.92 & 0.96 \\
\hline Final BW (kg) & 74.71 & 76.36 & 76.24 & 78.18 & 77.27 & 1.29 & 0.99 & 0.60 & 0.86 \\
\hline Weight gain $\left(\mathrm{kg} \mathrm{day}^{-1}\right)$ & $0.78^{b}$ & $0.78^{b}$ & $0.83^{\mathrm{ab}}$ & $0.83^{\mathrm{ab}}$ & $0.87^{\mathrm{a}}$ & 0.01 & 0.01 & 0.02 & 0.13 \\
\hline Feed intake $\left(\mathrm{kg} \mathrm{day}^{-1}\right)$ & 2.16 & 2.11 & 2.13 & 2.10 & 2.06 & 0.04 & 0.15 & 0.02 & 0.67 \\
\hline Feed efficiency & $0.36^{b}$ & $0.37^{b}$ & $0.38^{\mathrm{ab}}$ & $0.40^{\mathrm{ab}}$ & $0.42^{\mathrm{a}}$ & 0.01 & 0.06 & $<0.01$ & 0.07 \\
\hline $\begin{array}{l}\text { Digestible energy intake }\left(\mathrm{MJ} \mathrm{day}^{-1}\right) \\
78.6-105.8 \mathrm{~kg}\end{array}$ & 29.43 & 29.28 & 30.00 & 30.18 & 30.11 & 0.52 & 0.72 & 0.49 & 0.79 \\
\hline Initial BW (kg) & 78.65 & 78.94 & 78.39 & 78.29 & 78.61 & 0.25 & 1.00 & 0.94 & 1.00 \\
\hline Final BW (kg) & 104.33 & 105.50 & 105.85 & 106.40 & 107.16 & 1.06 & 0.98 & 0.52 & 0.81 \\
\hline Weight gain $\left(\mathrm{kg} \mathrm{day}^{-1}\right)$ & 0.92 & 0.95 & 0.98 & 1.00 & 1.02 & 0.01 & 0.09 & $<0.01$ & 0.01 \\
\hline Feed intake $\left(\mathrm{kg} \mathrm{day}^{-1}\right)$ & 3.10 & 2.98 & 2.96 & 2.94 & 2.90 & 0.08 & 0.33 & 0.04 & 0.11 \\
\hline Feed efficiency & $0.30^{b}$ & $0.32^{\mathrm{ab}}$ & $0.33^{a b}$ & $0.34^{\mathrm{ab}}$ & $0.35^{\mathrm{a}}$ & 0.30 & 0.05 & $<0.01$ & 0.01 \\
\hline Digestible energy intake (MJ day ${ }^{-1}$ ) & 42.26 & 41.31 & 41.77 & 42.18 & 42.40 & 0.45 & 0.93 & 0.70 & 0.76 \\
\hline
\end{tabular}

${ }^{x}$ A total of 480 pigs were used in Exp. 1, 420 pigs in Exp. 2 and 240 pigs in Exp. 3; $\mathrm{p}$-values for treatment are based on ANOVA using all five treatments; within a row, means followed by same or no letter do not differ $(\mathrm{p}>0.05)$ 
Table 6: Effects of dietary energy density on lean deposition of growing-finishing pigs reared in a commercial environment ${ }^{\mathrm{x}}$

\begin{tabular}{|c|c|c|c|c|c|c|c|c|c|}
\hline \multirow[b]{2}{*}{ Traits } & \multicolumn{5}{|c|}{$\mathrm{DE}\left(\mathrm{MJ} \mathrm{kg}^{-1}\right)$} & \multirow[b]{2}{*}{ SEM } & \multicolumn{3}{|l|}{$\mathrm{P}^{\mathrm{y}}$} \\
\hline & 13.62 & 13.87 & 14.12 & 14.37 & 14.62 & & ANOVA & Linear & Quadratic \\
\hline \multicolumn{10}{|l|}{$20.8-55.9 \mathrm{~kg}$} \\
\hline Hot carcass weight $(\mathrm{kg})$ & 37.03 & 35.38 & 36.98 & 37.47 & 34.27 & 0.53 & 0.28 & 0.37 & 0.44 \\
\hline Dressing percentage (\%) & 68.39 & 68.75 & 69.30 & 69.09 & 67.56 & 0.48 & 0.82 & 0.70 & 0.50 \\
\hline Back fat depth ${ }^{z}(\mathrm{~cm})$ & 1.00 & 0.95 & 1.01 & 1.19 & 1.05 & 0.03 & 0.12 & 0.29 & 0.47 \\
\hline Longissimus muscle area $\left(\mathrm{cm}^{2}\right)$ & $22.75^{\mathrm{a}}$ & $22.88^{\mathrm{a}}$ & $22.87^{\mathrm{a}}$ & $21.38^{\mathrm{ab}}$ & $18.83^{b}$ & 0.49 & 0.02 & 0.31 & $<0.01$ \\
\hline Fat-free lean gain $\left(g\right.$ g day $\left.{ }^{-1}\right)$ & 264.79 & 254.16 & 264.07 & 247.84 & 213.46 & 6.68 & 0.13 & 0.02 & 0.02 \\
\hline Fat-free lean index $(\%)$ & $57.29^{\mathrm{ab}}$ & $58.61^{\mathrm{a}}$ & $57.30^{\mathrm{ab}}$ & $54.51^{\mathrm{b}}$ & $55.16^{b}$ & 0.51 & 0.06 & 0.07 & 0.05 \\
\hline \multicolumn{10}{|l|}{$57.0-76.6 \mathrm{~kg}$} \\
\hline Hot carcass weight $(\mathrm{kg})$ & 57.36 & 57.84 & 56.72 & 57.52 & 59.12 & 0.46 & 0.60 & 0.34 & 0.36 \\
\hline Dressing percentage (\%) & $69.47^{\mathrm{bc}}$ & $72.31^{\mathrm{a}}$ & $68.53^{c}$ & $70.18^{\mathrm{abc}}$ & $71.48^{\mathrm{ab}}$ & 0.45 & 0.04 & 0.59 & 0.73 \\
\hline Back fat depth ${ }^{z}(\mathrm{~cm})$ & $2.07^{\mathrm{b}}$ & $1.99 \mathrm{~b}$ & $2.14^{\mathrm{b}}$ & $2.51^{\mathrm{ab}}$ & $2.87^{\mathrm{a}}$ & 0.11 & 0.03 & $<0.01$ & $<0.01$ \\
\hline Longissimus muscle area $\left(\mathrm{cm}^{2}\right)$ & 36.24 & 35.22 & 34.42 & 33.38 & 31.30 & 0.77 & 0.31 & 0.03 & 0.08 \\
\hline Fat-free lean gain $\left(g\right.$ g day $\left.{ }^{-1}\right)$ & $304.72^{\mathrm{a}}$ & $311.38^{\mathrm{a}}$ & $271.38^{\mathrm{ab}}$ & $233.57^{\mathrm{ab}}$ & $198.43^{b}$ & 14.40 & 0.05 & $<0.01$ & $<0.01$ \\
\hline Fat-free lean index $(\%)$ & $51.79^{\mathrm{a}}$ & $51.72^{\mathrm{a}}$ & $50.76^{\mathrm{a}}$ & $48.13^{\mathrm{ab}}$ & $45.09^{b}$ & 0.72 & $<0.01$ & $<0.01$ & $<0.01$ \\
\hline \multicolumn{10}{|l|}{$78.6-105.8 \mathrm{~kg}$} \\
\hline Hot carcass weight $(\mathrm{kg})$ & 73.13 & 75.87 & 77.20 & 74.27 & 75.87 & 1.37 & 0.28 & 0.39 & 0.32 \\
\hline Dressing percentage (\%) & 65.49 & 68.42 & 68.13 & 67.72 & 68.57 & 1.26 & 0.10 & 0.06 & 0.08 \\
\hline Back fat depth ${ }^{z}(\mathrm{~cm})$ & $1.95^{b}$ & $2.00^{b}$ & $2.00^{b}$ & $2.04^{\mathrm{b}}$ & $2.32^{\mathrm{a}}$ & 0.10 & $<0.01$ & $<0.01$ & $<0.01$ \\
\hline Longissimus muscle area $\left(\mathrm{cm}^{2}\right)$ & 41.65 & 41.31 & 40.64 & 39.82 & 37.76 & 1.34 & 0.09 & $<0.01$ & 0.20 \\
\hline Fat-free lean gain $\left(\mathrm{g}_{\text {day }}{ }^{-1}\right)$ & 330.23 & 343.71 & 352.65 & 299.18 & 272.98 & 11.00 & 0.05 & 0.10 & 0.02 \\
\hline Fat-free lean index $(\%)$ & $52.01^{\mathrm{a}}$ & $51.37^{\mathrm{a}}$ & $50.92^{\mathrm{a}}$ & $50.79^{\mathrm{a}}$ & $48.75^{b}$ & 0.29 & $<0.01$ & $<0.01$ & $<0.01$ \\
\hline
\end{tabular}

respectively. According to Baker (1986), the quadratic model indicates the requirements for maximal response of all animals in a population whereas a broken-line response predicts requirements for the average animal in the population. In the experiments, the quadratic or brokenline model was used to get the optimum dietary $\mathrm{DE}$ estimates under different conditions (Robbins et al., 2006). For pigs weighing $20.8-55.9 \mathrm{~kg}$ since, fat-free lean gain was higher in the three lower DE treatments than those values in the higher DE treatments there was not an increasing linear-plateau curve for a broken-line model. Under this condition, the quadratic model could give an estimate of the optimum dietary DE density for fat-free lean gain (Fig. 1a). However, for fat-free lean index during this period, the quadratic broken-line model gave a good estimate of the optimum DE concentration and the quadratic model gave a large underestimation for it as shown in Fig. 1b. Therefore, the broken-line model was used to estimate the requirement of DE density for fat-free lean index.

Conversely, the broken-line model and quadratic model were used to estimate the requirements for fat-free lean gain and fat-free lean index in the $57.0-76.7 \mathrm{~kg}$ period, respectively for similar reasons described (Fig. 2a, b). However, for pigs weighting $78.6-105.8 \mathrm{~kg}$, the quadratic model was used to estimate the optimum DE density for fat-free lean index.

Both the broken-line model and quadratic model gave a good estimation of the optimum energy level for fat-free lean gain. Therefore, the optimum energy level was the average of the three estimates. For fat-free lean gain of pigs weighing from $20.8-55.9 \mathrm{~kg}$ using the quadratic model, the data were fitted to a quadratic regression equation:

$$
\mathrm{Y}=-84.16 \mathrm{X}^{2}+2333.0 \mathrm{X}-15904.0\left(\mathrm{R}^{2}=0.89\right)
$$

The dietary DE concentration that maximized fat-free lean gain was calculated to be $13.86 \mathrm{MJ} \mathrm{DE} \mathrm{kg}^{-1}$ (Fig. 1a). However, a breakpoint of $13.76 \mathrm{MJ} \mathrm{DE} \mathrm{kg} \mathrm{kJ}^{-1}$ was determined for fat-free lean index using a broken-line model (Robbins et al., 2006) (Fig. 1b). Therefore, the optimum dietary $\mathrm{DE}$ density for lean deposition was 13.81 MJ DE kg$~^{-1}$, the average of the above two estimates. For pigs weighing from $57.0-76.6 \mathrm{~kg}$, the dietary $\mathrm{DE}$ concentration required to maximize lean deposition was 13.76 MJ DE kg-1, the average of $13.78 \mathrm{MJ} \mathrm{DE} \mathrm{kg}^{-1}$ (the breakpoint determined for fat-free lean gain using broken-line model) and 13.73 MJ DE kg-1 (estimated for fat-free lean index by the quadratic model:

$$
\mathrm{Y}=-8.697 \mathrm{X}^{2}+238.8 \mathrm{X}-1587.4, \mathrm{R}^{2}=(0.99)
$$

which are shown in Fig. 2. Finally, for pigs weighing from $78.6-105.8 \mathrm{~kg}$, the dietary $\mathrm{DE}$ concentration required to maximize lean deposition was $13.82 \mathrm{MJ} \mathrm{DE} \mathrm{kg}{ }^{-1}$, the average of $14.02 \mathrm{MJ} \mathrm{DE} \mathrm{kg}^{-1}$ (the optimum energy density for fat-free lean gain estimated from quadratic broken-line model:

$$
\mathrm{Y}=347.3-66.3(14.12-\mathrm{X})^{2}-157.2(\mathrm{X}-14.12), \mathrm{R}^{2}=(0.97)
$$

Quadratic model: 


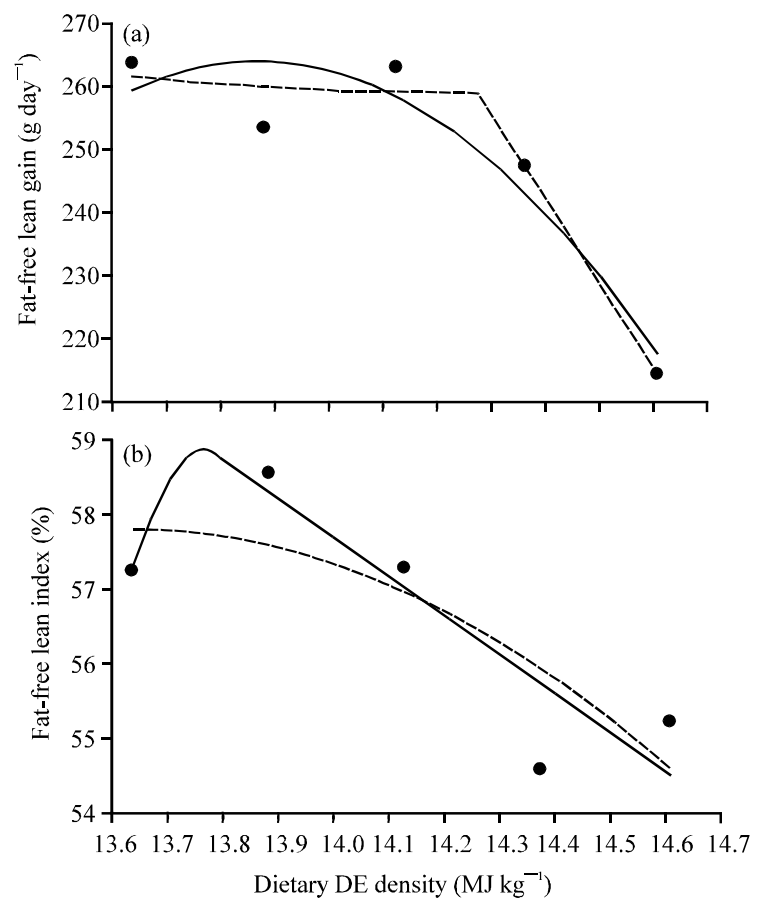

Fig. 1: Effect of DE density on fat-free lean gain (a) and fat-free lean index (b) in growing pigs weighing 20.8-55.9 kg (Exp.1) described with a broken-line and a quadratic model. a) Observed treatment mean values (-), a broken-line (---) and a quadratic (-) plot are shown. The quadratic model $\mathrm{Y}=-84.2 \mathrm{X}^{2}+2333 \mathrm{X}-15904, \mathrm{R}^{2}=0.89$ gave a better estimate of the dietary $\mathrm{DE}$ density for fat-free lean gain. The $\mathrm{DE}$ density that maximized fat-free lean gain was calculated to be 13.86 MJ DE kg ${ }^{-1}$. b: Observed treatment mean values (-), a broken-line (-) and a quadratic (---) plot are shown. The broken-line model was used to estimate the requirement of $\mathrm{DE}$ density for fat-free lean index. The equation was $\mathrm{Y}=58.96-89.57(13.76-\mathrm{X})^{2}-5.26(\mathrm{X}-13.76)$ $\left(\mathrm{R}^{2}=0.81\right)\left(\mathrm{R}^{2}=0.81\right)$ and the $\mathrm{DE}$ density that maximized fat-free lean index was calculated to be 13.76 MJ DE $\mathrm{kg}^{-1}$. Thus, the optimum level of dietary DE to maximize lean deposition was 13.81 MJ DE kg ${ }^{-1}$ for pigs weighing $20.8-55.9 \mathrm{~kg}$

$$
Y=-161.0 X^{2}+4484.0 X-30873, R^{2}=(0.90)
$$

and 13.62 MJ DE kg-1 (estimated for fat-free lean index by the quadratic model):

$$
\mathrm{Y}=-2.83 \mathrm{X}^{2}+77.2 \mathrm{X}-473.8, \mathrm{R}^{2}=(0.91)
$$

which are shown in Fig. 3.

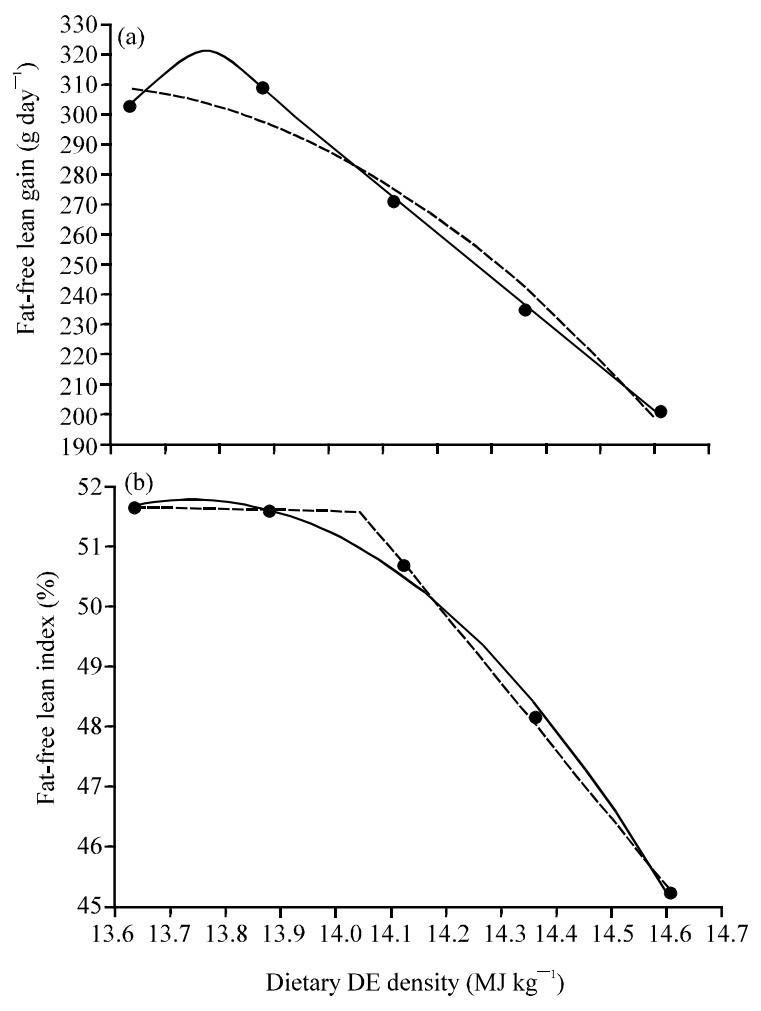

Fig. 2: Effect of DE density on fat-free lean gain (a) and fat-free lean index (b) in growing pigs weighing 57.0-76.6 kg (Exp. 2) described with a broken-line and a quadratic model. a) Observed treatment mean values $(-)$, a broken-line $(-)$ and a quadratic (---) plot are shown. The broken-line model was used the estimate the $\mathrm{DE}$ requirements for fat-free lean gain. The equation was $\mathrm{Y}=323.5$ $717.0(13.78-X)^{2}-150.7(X-13.78)\left(R^{2}=0.99\right)$ and the $\mathrm{DE}$ density that maximized fat-free lean gain was $13.78 \mathrm{MJ} \mathrm{DE} \mathrm{kg}^{-1}$. b) Observed treatment mean values (-), a broken-line (---) and a quadratic (-) plot are shown. The quadratic $\operatorname{model}\left(\mathrm{Y}=-8.70 \mathrm{X}^{2}+238.8 \mathrm{X}-1587.0, \mathrm{R}^{2}=0.99\right)$ gave a better estimate of the $\mathrm{DE}$ density for fat-free lean index. The $\mathrm{DE}$ density that maximized fat-free lean

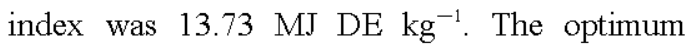
level of $\mathrm{DE}$ to maximize lean deposition was 13.76 MJ DE kg ${ }^{-1}$

Growth performance: Increases in weight gain of growing pigs as the dietary energy concentration increases have been reported by previous studies (Urynek and Buraczewska, 2003; Campbell and Taverner, 1988). Bikker et al. (1995) also showed that young pigs from $20-45 \mathrm{~kg}$ were energy-dependent. In contrast, in Exp. 1 of the present study, energy density had no effects 


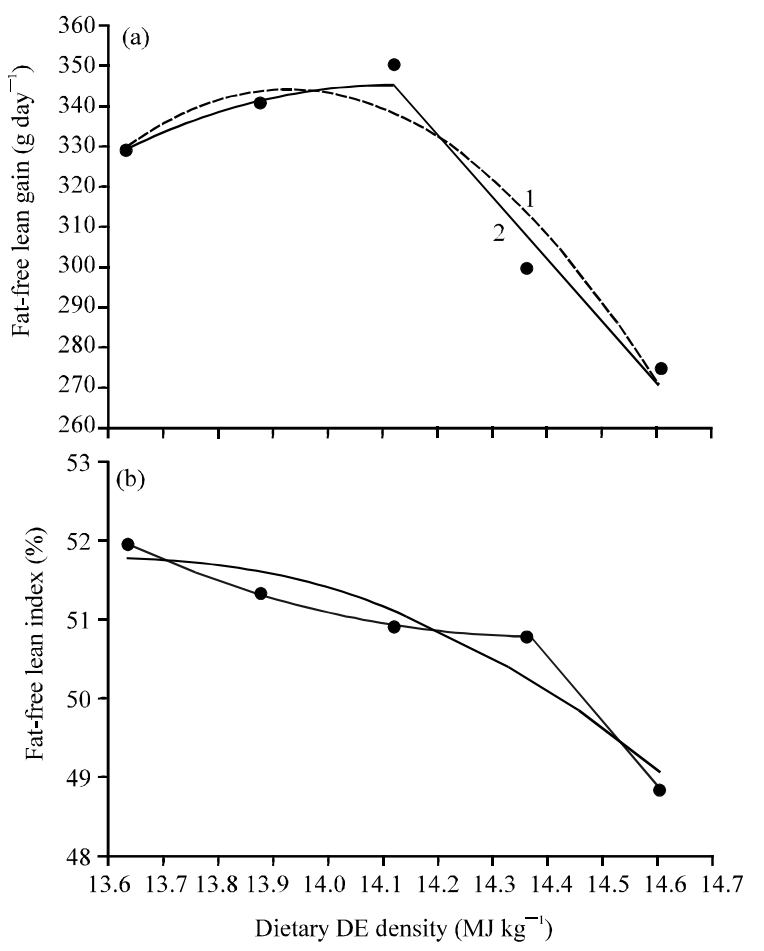

Fig. 3: Effect of DE on fat-free lean gain (a) and fat-free lean index (b) in finishing pigs weighing 78.6-105.8 kg (Exp. 3) described with a broken-line and a quadratic model. Observed treatment mean values (-), a quadratic (---, Curve 1) and a broken-line (-, black, Curve 2) plot are shown. Both the broken-line model $(\mathrm{Y}=347.3-66.3$ $\left.(14.12-\mathrm{X})^{2}-157.2(\mathrm{X}-14.12), \mathrm{R}^{2}=0.97\right)$ and the quadratic model $\left(\mathrm{Y}=-161.0 \mathrm{X}^{2}+4484.0 \mathrm{X}-30873\right.$, $\mathrm{R}^{2}=0.90$ ) were used to estimate the $\mathrm{DE}$ requirement for fat-free lean gain. The optimal dietary level of $14.02 \mathrm{MJ} \mathrm{DE} \mathrm{kg} \mathrm{kg}^{-1}$ was the average of the two estimates. The quadratic model $\left(\mathrm{Y}=-2.83 \mathrm{X}^{2}+77.2 \mathrm{X}-473.8, \mathrm{R}^{2}=0.91\right)$ gave a good estimate of the $\mathrm{DE}$ density for fat-free lean index. The DE density that maximized it was calculated to be $13.62 \mathrm{MJ} \mathrm{DE} \mathrm{kg}{ }^{-1}$. Thus, the optimum level of $\mathrm{DE}$ to maximize lean deposition was $13.82 \mathrm{MJ} \mathrm{DE} \mathrm{kg}^{-1}$

on weight gain and feed efficiency in $20.8-55.9 \mathrm{~kg}$ pigs. This result was surprising but it was similar to that reported by Stahly et al. (1981) wherein increasing dietary energy level did not affect $(\mathrm{p}>0.10)$ the rate of gain and feed conversion in growing $(20-60 \mathrm{~kg})$ pigs. The explanation for the failure to observe a response in weight gain in the $20.8-55.9 \mathrm{~kg}$ period due to increasing energy concentration in the present study may be attributed to a reduction of lysine to $\mathrm{DE}$ ratio as the $\mathrm{DE}$ level increased.
In the study, researchers increased dietary DE concentration but kept the lysine level constant among the five treatments which resulted the lysine to $\mathrm{DE}$ ratio decreased from 3.01-2.72 $\mathrm{g}$ lysine $\mathrm{Mcal}^{-1} \mathrm{DE}$ as the dietary energy increased. Decreases in weight gain in response to a reduction in lysine to $\mathrm{DE}$ ratio have been reported by many previous studies (Campbell et al., 1985; Fuller et al., 1986). Thus, the combination of increased dietary energy concentration and decreased lysine to $\mathrm{DE}$ ratio might resulte in no differences in weight gain in this period (Table 5).

However, in the research of Chiba et al. (1991a), which was conducted in $20-50 \mathrm{~kg}$ pigs when the lysine level of the diet was $0.96 \%$, similar to the level in the study, weight gain decreased linearly $(\mathrm{p}=0.01)$ with an increase in DE concentration and feed efficiency increased linearly $(p=0.001)$ from $0.41-0.52$. The differences between these two studies may be due to the $\mathrm{DE}$ levels used in the two studies being different. In the study of Chiba et al. (1991 a), the four DE levels were 3.00, $3.50,3.75,4.00 \mathrm{Mcal} \mathrm{kg}^{-1}$ whereas in the research, they ranged from $3.25-3.50 \mathrm{Mcal} \mathrm{kg}^{-1}\left(13.62-14.62 \mathrm{MJ} \mathrm{kg}^{-1}\right.$ ). The quadratic tendency for feed intake was surprising and was not observed in previous studies evaluating energy density in pig diets (Urynek and Buraczewska, 2003; Nam and Aherne, 1994). The high feed intake observed for pigs fed 14.37 and $14.62 \mathrm{MJ} \mathrm{DE} \mathrm{kg}^{-1}$ diets might be due to the low lysine to $\mathrm{DE}$ ratio for these two treatments compared with the other treatments. In these two treatments, pigs needed to consume more feed to meet their lysine requirements for growth and tissue deposition. However, for pigs fed the $13.62 \mathrm{MJ} \mathrm{DE} \mathrm{kg}^{-1}$ diet, pigs likely consumed more feed probably to meet their energy requirement.

There were no breakpoints in the data of weight gain response to energy concentration analyzed by broken-line model in the research since weight gain was not affected by energy density in the $20.8-55.9 \mathrm{~kg}$ period. Thus, lower energy density should be adopted in the future to get the dietary DE requirement for growth performance of pigs in this period.

Increasing the dietary energy density of pigs from $57.0-76.6 \mathrm{~kg}$ and $78.6-105.8 \mathrm{~kg}$ (finishing period) both linearly increased weight gain and feed efficiency as well as linearly decreased feed intake. Consistent with the present study, Campbell and Taverner (1988) reported that pigs $(45-90 \mathrm{~kg}$ ) were in an energy-dependent stage of growth. Similarly, the study of Beaulieu et al. (2009) which was conducted at a commercial swine farm, found that weight gain and feed efficiency improved with increased energy concentration when diets providing $3.12,3.30$ or 3.43 Mcal of $\mathrm{DE} \mathrm{kg}^{-1}$ were fed to pigs during the $57-79 \mathrm{~kg}$ 
period. In contrast to the present study, Smith et al. (1999) observed that weight gain decreased quadratically $(\mathrm{p}<0.05)$ when the dietary energy level was increased for pigs $(72.6-104.3 \mathrm{~kg})$. Matthews et al. $(1998,2003)$, Kerr et al. (2003) and Apple et al. (2004) also observed that increasing the energy density of finishing swine diets had no appreciable effect on weight gain. These differences might be due to energy system, dietary energy density or whether crystalline amino acid being supplemented when the dieatry energy concentration was increased.

There were no breakpoints in the data of the weight gain response to energy concentration analyzed by broken-line model in the research since weight gain was not affected by energy density in the 20.8-55.9 kg period and it increased with increasing dietary DE level in the 57.0-76.6 and 78.6-105.8 kg periods. A larger energy concentration range should be adopted in the future research conducted to determine the effects of dietary energy density on growth performance of growingfinishing pigs.

Lean deposition: Lean growth is measured as lean gain per day of age (Fowler et al., 1976) and considered to be the most appropriate expression of industry's objective for market pigs (Chen et al., 2002). Fat-free lean predicted from carcass weight and measures of backfat depth and longissimus muscle surface area determines the value of pork carcasses in most markets. In the study, researchers used the carcass fat-free lean gain and fat-free lean index as published in NRC (1998) to describe lean deposition. Several factors such as genetic type, hormone level, dietary nutrient level and dietary supplement have driven research investigating the control of lean deposition in pigs. The findings in which pork carcasses tended to be fatter in response to elevating the dietary energy level were in agreement with the results of others (Apple et al., 2004; Myer et al., 1992; Bee et al., 2002). In the research of Myer et al. (1992) a group of growing-finishing pigs (from $33-102 \mathrm{~kg}$ ) were given different $\mathrm{ME}$ level diets (3330,

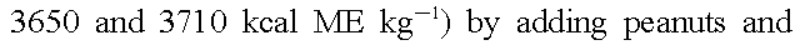
canola oil and average back fat was observed to increase from 3.5-3.8 $\mathrm{cm}$ and there was no difference about longissimus muscle area among the treatments. Bee et al. (2002) also found that 13th-rib back fat depth of pigs $(27-105 \mathrm{~kg})$ decreased and lean growth rate increased when dietary DE level decreased from 14.1-8.8 $\mathrm{MJ} \mathrm{kg}^{-1}$. Apple et al. (2004) reported that elevating energy levels from 3.30-3.48 $\mathrm{Mcal} \mathrm{ME} \mathrm{kg}^{-1}\left(13.81-14.56 \mathrm{MJ} \mathrm{ME} \mathrm{kg}^{-1}\right)$ for pigs weighing $84.3 \mathrm{~kg}$ resulted in an increase of back fat and a decrease of fat-free lean gain but had no effect on longissimus muscle area. Different results were also observed in other reports. Knowles et al. (1998) reported few effects of dietary energy levels on carcass traits of pigs (74-110 kg) and pigs fed the lowest level of dietary energy had greater 10th rib back fat depth whereas estimated lean percentage did not differ.

Several researchers have also demonstrated no differences in carcass traits when pigs were fed diets containing different energy densities (Smith et al., 1999; De La Llata et al., 2001a, b). The diverse results from the studies might be due to different dietary energy range.

In the research, the trend of decreased carcass lean and increased back fat depth with the increasing $\mathrm{DE}$ concentration of diets indicates that at low energy levels, pigs have a preference for protein deposition whereas the proportion of fat to gain increases at higher energy levels. This is in agreement with Apple et al. (2004) who reported that pigs fed high energy level diets deposited proportionately more fat and less muscle relative to pigs fed a low energy level diet. Similar results were also observed in the study of Chiba et al. (1991b) when dietary lysine level was $0.96 \%$ (similar to the dietary level in Exp. 1), protein deposition decreased from 112.2-102.2 $\mathrm{g} \mathrm{day}^{-1}$ while the $\mathrm{DE}$ level increased from $3.00-3.50 \mathrm{Mcal} \mathrm{kg}^{-1}$. In addition to energy level, lysine to $\mathrm{DE}$ ratio can also affect the composition of pigs. Szabo et al. (2001) reported that lowering the lysine to DE ratio increased $(p<0.05)$ crude fat and fatty tissue content and decreased $(\mathrm{p}<0.05)$ protein and muscle content in the body of pigs during $60-105 \mathrm{~kg}$. The reduction of fat-free lean gain in the study may also be attributed to the decreasing lysine to $\mathrm{DE}$ ratio as the energy level increased.

According to the quadratic and broken-line model analysis about the requirement of dietary $\mathrm{DE}$ concentration for lean deposition, the maximum fat-free lean gain was 265,323 and $348 \mathrm{~g}_{\text {day }}{ }^{-1}$ for the 20.8-55.9, $57.0-76.6$ and $78.6-105.8 \mathrm{~kg}$ periods, respectively. Since, $100 \mathrm{~g}$ of body protein deposition is equivalent to $255 \mathrm{~g}$ of fat-free lean tissue gain (NRC, 1998), the maximum of Protein deposition (Pd max) for these three periods was $104.18,126.7$ and $136.5 \mathrm{~g} \mathrm{day}^{-1}$, respectively. The values for Pd max determined in the current study fell within the higher region of the range of published values for Pd max of 90 to in excess of $200 \mathrm{~g}^{\text {day }}{ }^{-1}$ (Whittemore, 1983; Whittemore et al., 2001). According to the latter finding, rate of $\mathrm{Pd}$ max increased with increasing body weight and the results of the present study were in consistent with it. Whereas in the study of Moughan et al. (2006) over the body weight range of 25-85 kg, Pd max was constant for entire male and female pigs at 170 and $147 \mathrm{~g} \mathrm{day}^{-1}$, respectively. The discrepancy may be due to the fact that different response models were applied in these studies that led to different 
interpretations concerning $\mathrm{Pd} \max$ and the choice of statistical models has an important effect upon the conclusions drawn concerning the relationship between Pd max and body weight. An increasing rate of Pd max with increasing body weight for entire males and a decreasing rate of $\mathrm{Pd}$ max with increasing body weight for females was concluded when the quadratic model was used in researchers of Moughan et al. (2006) whereas a constant response conclusion was obtained with the linear model.

\section{CONCLUSION}

The results of the present study demonstrate that larger energy range should be adopted to get the $\mathrm{DE}$ requirement for growth performance. The optimal dietary DE to maximize lean deposition was different for the three growing-finishing phases. Pigs require different dietary energy levels for lean deposition compared with performance. Therefore, diets may be formulated with different energy levels depending on the overall goal of a swine producer.

\section{IMPLICATIONS}

A larger energy density range should be adopted in the future research about optimum dietary energy concentration for performance. The optimum energy density for lean deposition was 13.81, 13.76 and $13.82 \mathrm{MJ} \mathrm{kg}^{-1}$ for $20.8-55.9,57.0-76.6$ and $78.6-105.8 \mathrm{~kg}$ pigs, respectively. Different dietary energy levels are required to optimize lean deposition compared with growth performance for growing-finishing pigs which suggests that different energy requirements for different emphasis should be included in the NRC recommendations, instead of the current constant energy level of $3400 \mathrm{kcal} \mathrm{DE} \mathrm{kg}^{-1}$ for all stages of pig growth. Also, the required differences in energy density indicated an optimal feeding strategy about dietary energy level can only be designed after appropriate definition of the desired product and market situations.

\section{ACKNOWLEDGEMENTS}

This study was supported by the National Natural Science Foundation of the Peoples Republic of China (NO. 30525029). The researchers wish to thank Dr. Phil Thacker for the helpful disscussion of the manuscript.

\section{REFERENCES}

AOAC, 1990. Official Methods of Analysis. 15th Edn., Association of Official Analytical Chemists, Washington DC., USA., pp: 200-210.
Apple, J.K., C.V. Maxwell, D.C. Brown, K.G. Friesen, R.E. Musser, Z.B. Johnson and T.A. Armstrong, 2004. Effects of dietary lysine and energy density on performance and carcass characteristics of finishing pigs fed ractopamine. J. Anim. Sci., 82: 3277-3287.

Baker, D.H., 1986. Problems and pitfalls in animal experiments designed to establish dietary requirements for essential nutrients. J. Nutr., 116: 2339-2349.

Beaulieu, A.D., N.H. Williams and J.F. Patience, 2009. Response to dietary digestible energy concentration in growing pigs fed cereal grain-based diets. J. Anim. Sci., 87: 965-976.

Bee, G., S. Gebert and R. Messikommer, 2002. Effect of dietary energy supply and fat source on the fatty acid pattern of adipose and lean tissues and lipogenesis in the pig. J. Anim. Sci., 80: 1564-1574.

Bikker, P., V. Karabinas, M.W. Verstegen and R.G. Campbell, 1995. Protein and lipid accretion in body components of growing gilts $(20-45 \mathrm{~kg})$ as affected by energy intake. J. Anim. Sci., 73: 2355-2363.

Black, J.L., 1995. Modelling Energy Metabolism in the Pig-Critical Evaluation of a Simple Reference Model. In: Modelling Growth in the Pig, Moughan, P.J., M.W.A. Verstegen and M.I.V. Reyneveld (Eds.). Wageningen Press, Wageningen, The Netherlands, ISBN: 9789074134224, pp: 87-102.

Campbell, R.G. and A.C. Dunkin, 1983. The effects of energy intake and dietary protein on nitrogen retention, growth performance, body composition and some aspects of energy metabolism of baby pigs. Br. J. Nutr., 49: 221-230.

Campbell, R.G. and M.R. Taverner, 1988. Intake and protein deposition in growing pigs genotype and sex effects on the relationship between energy. J. Anim. Sci., 66: 676-686.

Campbell, R.G., M.R. Taverner and D.M. Curic, 1985. The influence of feeding level on the protein requirement of pigs between 20 and $45 \mathrm{~kg}$ live weight. Anim. Prod., 40: 489-496.

Chen, P., T.J. Baas, J.W. Mabry, J.C.M. Dekkers and K.J. Koehler, 2002. Genetic parameters and trends for lean growth rate and its components in U.S. Yorkshire, Duroc, Hampshire and Landrace pigs. J. Anim. Sci., 80: 2062-2070.

Chiba, L.I., A.J. Lewis and E.R. Peo Jr., 1991a. Amino acid and energy interrelationships in pigs weighing $20-50 \mathrm{~kg}$ : I. Rate and efficiency of weight gain. J. Anim. Sci., 69: 694-707. 
Chiba, L.I., A.J. Lewis and E.R. Peo Jr., 1991b. Amino acid and energy interrelationships in pigs weighing $20-50 \mathrm{~kg}$ : II. Rate and efficiency of protein and fat deposition. J. Anim. Sci., 69: 708-718.

China Feed Bank, 2006. Tables of Feed Composition. Chinese Academy of Agricultural Sciences, Beijing, China.

De La Llata, M., S.S. Dritz, M. Langemeier, M.D. Tokach, R.D. Goodband and J.L. Nelssen, 2001a. Economics of increasing lysine: Calorie ratio and adding dietary fat for growing-finishing pigs reared in a commercial environment. J. Swine Health Prod., 9: 215-223.

De La Llata, M., S.S. Dritz, M.D. Tokach, R.D. Goodband, J.L. Nelssen and T.M. Loughin, 2001b. Effects of dietary fat on growth performance and carcass characteristics of growing-finishing pigs reared in a commercial environment. J. Anim. Sci., 79: 2643-2650.

Fairbairn, S.L., J.F. Patience, H.L. Classen and R.T. Zijlstra, 1999. The energy content of barley fed to growing pigs: Characterizing the nature of its variability and developing prediction equations for its estimation. J. Anim. Sci., 77: 1502-1512.

Fowler, V.R., M. Bichard and A. Pease, 1976. Objectives in pig breeding. Anim. Prod., 23: 365-387.

Fuller, M.F., J. Wood, A.C. Brewer, K. Pennie and R. MacWilliam, 1986. The responses of growing pigs to dietary lysine, as free lysine hydrochloride or in soya-bean meal and the influence of food intake. Anim. Prod., 43: 477-484.

Johnson, R.K., E.P. Berg, R. Goodwin, J.W. Mabry and R.K. Miller et al., 2004. Evaluation of procedures to predict fat-free lean in swine carcasses. J. Anim. Sci., 82: 2428-2441.

Kerr, B.J., L.L. Southern, T.D. Bidner, K.G. Friesen and R.A. Easter, 2003. Influence of dietary protein level, amino acid supplementation, and dietary energy levels on growing-finishing pig performance and carcass composition. J. Anim. Sci., 81: 3075-3087.

King, R.H., 1999. Nutritional Constraints to Pig Performance and Variability. In: Manipulating Pig Production VII, Cranwell, P.D. (Ed.). Australasian Pig Science Association, Victoria, Australia, pp: 245-251.

Knowles, T.A., L.L. Southern, T.D. Bidner, B.J. Kerr and K.G. Friesen, 1998. Effect of dietary fiber or fat in low-crude protein, crystalline amino acidsupplemented diets for finishing pigs. J. Anim. Sci., 76: 2818-2832.

Kyriazakis, I. and G.C. Emmans, 1992a. The effects of varying protein and energy intakes on the growth and body composition of pigs 1 . The effects of energy intake at constant, high protein intake. Br. J. Nutr., 68: 603-613.
Kyriazakis, I. and G.C. Emmans, 1992b. The effects of varying protein and energy intakes on the growth and body composition of pigs. 2. The effects of varying both energy and protein intake. Br. J. Nutr., 68: 615-625.

Lawrence, B.V., O. Adeola and T.R. Cline, 1994. Nitrogen utilization and lean growth performance of $20-50 \mathrm{~kg}$ pigs fed diets balanced for lysine: Energy ratio. J. Anim. Sci., 72: 2887-2895.

Llames, C.R. and J. Fontaine, 1994. Determination of amino acids in feeds: Collaborative study. J. AOAC Int., 77: 1362-1402.

Matthews, J.O., A.D. Higbie, L.L. Southern, D.F. Coombs, T.D. Bidner and R.L. Odgaard, 2003. Effect of chromium propionate and metabolizable energy on growth, carcass traits and pork quality of growingfinishing pigs. J. Anim. Sci., 81: 191-196.

Matthews, J.O., L.L. Southern, J.E. Pontif, A.D. Higbie and T.D. Binder, 1998. Interactive effects of betaine, crude protein and net energy in finishing pigs. J. Anim. Sci., 76: 2444-2455.

Moughan, P.J., L.H. Jacobson and P.C.H. Morel, 2006. A genetic upper limit to whole-body protein deposition in a strain of growing pigs. J. Anim. Sci., 84: 3301-3309.

Myer, R.O., D.D. Johnson, D.A. Knauft, D.W. Gorbet, J.H. Brendemuhl and W.R. Walker, 1992. Effect of feeding high-oleic-acid peanuts to growing-finishing swine on resulting carcass fatty acid profile and on carcass and meat quality characteristics. J. Anim. Sci., 70: 3734-3341.

NRC, 1998. Nutrient Requirements of Swine. 10th Edn., Natl. Acad. Press, Washington, DC.

Nam, D.S. and F.X. Aherne, 1994. The effects of lysine:energy ratio on the performance of weanling pigs. J. Anim. Sci., 72: 1247-1256.

Noblet, J., H. Fortune, S. Dubois and Y. Henry, 1989. New basis for estimating levels of digestible energy, metabolizable and net of feeds for pigs. National Institute of Agronomic Research, Paris.

Robbins, K.R., A.M. Saxton and L.L. Southern, 2006. Estimation of nutrient requirements using broken-line regression analysis. J. Anim. Sci., 84: E155-E165.

Smith, J.W. 2nd, M.D. Tokach, P.R. O'Quinn, J.L. Nelssen and R.D. Goodband, 1999. Effects of dietary energy density and lysine: Calorie ratio on growth performance and carcass characteristics of growing-finishing pigs. J. Anim. Sci., 77: 3007-3015. 
Stahly, T.S., G.L. Cromwell and J.R. Overfield, 1981. Interactive effects of season of year and dietary fat supplementation, lysine source and lysine level on the performance of swine. J. Anim. Sci., 53: 1269-1277.

Szabo, C., A.J. Jansman, L. Babinszky, E. Kanis and M.W. Verstegen, 2001. Effect of dietary protein source and lysine: DE ratio on growth performance, meat quality and body composition of growingfinishing pigs. J. Anim. Sci., 79: 2857-2865.

Urynek, W. and L. Buraczewska, 2003. Effect of dietary energy concentration and apparent ileal digestible lysine:metabolizable energy ratio on nitrogen balance and growth performance of young pigs. J. Anim. Sci., 81: $1227-1236$.
Weis, R.N., S.H. Birkett, P.C.H. Morel and C.F.M. de Lange, 2004. Effects of energy intake and body weight on physical and chemical body composition in growing entire male pigs. J. Anim. Sci., 82: 109-121.

Whittemore, C.T., 1983. Development of recommended energy and protein allowances for growing pigs. Agric. Syst., 11: 159-186.

Whittemore, C.T., D.M. Green and P.W. Knap, 2001. Technical review of the energy and protein requirements of growing pigs: Protein. Anim. Sci., 73: $363-373$. 